\title{
個人撮影映像を対象とした映像速覧のための“笑い”シーン 検出法
}

\section{A Video Skimming Method for Detecting "Laughter" Scenes in Consumer Generated Videos}

\author{
入江 豪 ${ }^{\dagger}$ 日高浩 $太^{\dagger}$, \\ 正会員佐藤隆 ${ }^{\dagger}$, 正会員谷口行信 ${ }^{\dagger}$
}

Go Irie $^{\dagger}$, Kota Hidaka ${ }^{\dagger}$, Naoya Miyashita ${ }^{\dagger}$, Takashi Satou ${ }^{\dagger}$ and Yukinobu Taniguchi ${ }^{\dagger}$

\begin{abstract}
A method is described for detecting a "laughter" scene in a Consumer Generated Video (CGV). The growing number of CGVs is growing, so a video skimming method that allows viewers to quickly find "enjoyable" scenes would be useful. An experiment showed that viewers tend to find CGVs that include a "laughter" scene "enjoyable". On that basis, we developed a method for detecting "laughter" scenes using prosodic information such as pitch, energy, power spectrum densities and their differential components to estimate the probability of laughter in the soundtrack. In this method, a generalized state space model, which consists of acoustic models and a state-transition model, calculates the probability of laughter to detect a "laughter" scene. An experiment showed that the precision rate of the method was about $83 \%$, which suggests that the method enables effective video skimming.
\end{abstract}

キーワード：韻律，CGV，シーン検出，速覧，笑い。

\section{1. まえがき}

光・ブロードバンド網の普及が進み，一般利用者が Web 上での映像視聴・共有を楽しむ機会が増加してきた。これ に伴い, 個人撮影映像を代表とする消費者生成映像（Consumer Generated Video: CGV) の数は爆発的に増加して いる．映像は，静止画像とは異なり，時間軸を持ったメディ アである。このため，内容確認には時間がかかり，膨大な 数の映像の中から見たい映像を探し出し，実際に視聴する という基本的な行為そのものに多大な時間が必要となる.

この問題に対して筆者らは，映像視聴を効率的に短時間 化する，映像速覧技術の研究に取り組んできた。これまで, 映像中の強調された音声区間に着目してダイジェストを生 成する手法を提案し ${ }^{1)}$ ，この手法を応用したインターネッ 卜上の映像をダイジェスト配信するシステムについて，そ の有効性を確認してきた ${ }^{2) 3)}$ 。この技術は，強調された音 声の検出という単一の指噤に基づく映像速覧技術となって いるが，視聴者の映像に対する興味や嗜好も多様化してき ていることから，今後はこれらをより反映した指標に基づ

2007 年 7 月 3 日受付, 2007 年 9 月 3 日再受付, 2007 年 10 月 12 日採録

†日本電信電話株式会社 NTT サイバーソリューション研究所

（† 239-0847 神奈川県横須賀市光の丘 1-1, TEL 046-859-2305)

$\dagger$ NTT Cyber Solutions Laboratories, NTT Corporation

(1-1 Hikarinooka Yokosuka-Shi, Kanagawa, 239-0847 Japan)
く映像速覧技術が求められていくと予想される。

このような指標の一つとして，感性的な印象があげられ る。これは, “楽しい”, “泣ける”などといった印象語で 表現されるものである，実際に映像を紹介する場面や，映 像に対する感想を記載した blog やサイトでは，このよう な印象語を使ったレビューが多数確認できる。また，最近， 映画やDVD などの商用の編集映像を対象に，これらを印 象語に基づいて探すことのできるサイトが出始めてきてい る ${ }^{4) 5)}$. このような事実から，視聴者の映像に対する嗜好 は, “楽しい”, “泣ける”などの視聴時の感性的な印象と いう形で表現しやすく，印象に基づく映像速覧を実現する ことによって，前述の課題に対して有効な解決を与えるこ とができると考えられる。

本研究では, 一般利用者が汎用の撮影㙨器を用いて撮影 した個人撮影映像を CGV として定義し，これを対象とし て，印象に基づく映像速覧技術の確立を目指す。本稿では， 多様な印象の中でも，基本的なものである “楽しい”印象 に着目し，この印象に則したシーンを速覧する方法を検討 する．映像の中でも，“笑い”のあるシーンを視聴した場合， 視聴者は“楽しい”という印象を持ちやすいと想定される. このことに着目し，本稿では，CGV中の“笑い”シーンを 自動的に検出する方法を提案する. 以降，本稿では，2で， 関連研究を示し，これらの研究に対する本研究の位置づけ 
表 1 編集映像と CGV の映像・音声的特徵 Visual and audio characteristics of edited content and CGV.

\begin{tabular}{c|l|l}
\hline \hline & 編集映像 & CGV \\
\hline 画質 & カメラワークが明確で & 手振れ, 露光状況による \\
& $\begin{array}{c}\text { 露光調整がされている. } \\
\text { 変動が大きい゙. }\end{array}$ \\
\hline 編集 & カット点が存在する. & カット点が存在しない. \\
\hline 発話音声 & 明瞭で聴取しやすい. & 不明瞭で聴取しにくい. \\
\hline 雑音 & 収音されているため, & 雑音レベルが大きい. \\
& 雑音レベルが小さい. & \\
\hline
\end{tabular}

を明確にする．３では，“笑い”シーンを含む映像を視聴し た場合，“楽しい”という印象を持ちやすい傾向にあること を確認した被験者実験の結果を示す。 4 では，“笑い”シー ンを検出する方法を提案し，5で提案手法の検出精度を評 価した実験結果を示す。

\section{2. 関連研究と本研究の位置づけ}

映像の印象を分析する場合, 映像中の感情や感情表出, 特 徵的なイベントが大きな手掛かりとして利用できる。この ようなアプローチの下, 最近, 映像中の感情や情動, 感性 的なイベントを検出する方法がいくつか報告されている.

例えば, Kangの方法は，色ヒストグラム，カメラワーク， カット点頻度を映像特徽量として抽出し，これらに基づい て “Joy”, “Sadness”, “Fear”の三つの感情それぞれを, 隠れマルコフモデル (Hidden Markov Models: HMMs) を用いた尤度計算によって検出している ${ }^{6)}$. Xu らの方法 は, 映像中の音声情報に着目し, 音韻に関する特徵量であ るメル尺度ケプストラム係数 (Mel Frequency Cepstrum Coefficient: MFCC)，韻律特徵量である振幅などを特徴 量とし, HMMsを用いて “Canned Laughter”や“Horror Sound”など，コメディやホラー映画に挿入される音声イ ベントを検出するものである ${ }^{7)}$. Hanjalic らの方法は, 映 像情報と音声情報両方を用いた方法である ${ }^{8)}$. 映像特徽量 であるショット長，カメラワークや，韻律特徴量である基 本周波数, 振幅などの特徴量と,「情動二要因」として知ら れる「覚醒度 (arousal)」,「感情価 (valence)」のそれぞ れに対応付けてモデル化し, 映像の情動性を分析している.

ここに挙げた方法は，映画やスポーツ番組などに代表さ れる，商用の編集映像を刘象とした方法となっている．従 来より, 編集映像に対する技術・方法は盛んに研究されて きたものの，最近増加してきている CGVに対しては，ほ とんど取組みがなされていないのが現状である。編集映像 と CGV の映像的特徵, 音声的特徵を表 1 にまとめる. 編 集映像は，高度な撮影・編集装置を使用し，さらに専門家 によって撮影・編集されているため, 画質・音質共に良好で あり，カット点，カメラワークや，“Canned Laughter”, “Horror Sound” などの編集情報が利用可能である点で, 扱いやすい対象であるといえる。一方, CGVは，このよう な質の高い撮影・編集工程を経ておらず，画質・音質も良 好ではないことや，編集情報も利用できないことから，解
析しにくい対象となる．映像的特徴としては，撮影時の手 ブレによる画面摇れが大きく，画角が明確でない場合が多 い.また，劣悪な露光条件下で撮影されることも多い。こ のため, 映像特徵量を解析して有益な情報を抽出すること が難しい，また，収音装置を介さずに撮影されることが多 いため，環境音などによる雑音レベルが大きく，この影響 を受けやすい高次の音韻特徵量は非常に不安定になること が多い. したがって，このような CGVの性質を考慮した 手法を検討する必要があり, 筆者らはこの研究に取り組ん でいる9)10).

表 1 に示すような繁雑な性質を有する CGVにおいても， 目的となる“笑い”シーン検出を実現するため, 提案手法 では韻律特徴量に着目する。韻律特徴量は，スペクトル情 報のうち，雑音の影響を受けにくい低次のスペクトル情報 を解析することで抽出できる。このため, CGVにおいて も，比較的安定して抽出しやすいという利点がある。また， 音声の印象や感情は, 韻律特徵量を代表としたノンバーバ ルな情報に表れやすいという特徵を備えていることが知ら れている ${ }^{11)}$ 。これまでにも，音声対話型エージェントの構 築などを目的として，韻律特徵量を用いた感情の認識手法

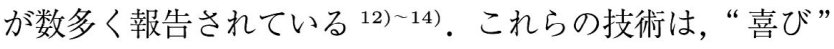
や“怒り”といった話者感情の認識を目的としており，本稿 で対象とする“笑い”についての検討は充分になされてい ない. “笑い”については, 基礎解析や模索的な研究例は報 告されているものの ${ }^{15) 16)}$ ，一般的な検出法の確立には至っ ていない.

\section{3. “笑い”シーンの印象について}

本稿では, “笑い”シーンの検出によって“楽しい”シー ンを速覧する手段を提供することを狙いとしている。しか しながら，“笑い”シーンの視聴によって，視聴者が“楽 しい”印象を持つかどうかは自明ではない。 そこで本章で は,「“笑い”シーンを含む CGV を視聴した場合，視聴者 が“楽しい”という印象を持ちやすい」という仮説を立て， これを被験者実験により検証した。

$\mathrm{CGV}$ において，“笑い”シーンを含む映像（A 群）と， 含まない映像（B 群）を，調査対象とした。被験者の夕ス クは， $\mathrm{A}$ 群と $\mathrm{B}$ 群の映像を無作為な順序で視聴し，各映像 について，印象の評価值を 5 段階（0：楽しいと思わない 1 ：あまり楽しいと思わない，2：どちらともいえない，3： まあ楽しいと思う，4：楽しいと思う）で評価することであ る。実験に利用する CGV は，筆者らの映像共有実験サイ ト「ClipLife」17)に公開されているものを利用した。この 際，利用する映像は，速覧に近い状況を想定して比較的映 像の時間（長さ）の短い，30〜90秒のものに限定し，88 本 をランダムに抽出した。このうち $\mathrm{A}$ 群, B 群の映像数は, それぞれ 11 本， 77 本とした. 被験者は 6 名（20 代 30 代 の男女各 3 名）とした。

$\mathrm{A}$ 群，B 群ごとの印象の評価值を，正規化したヒストグ 


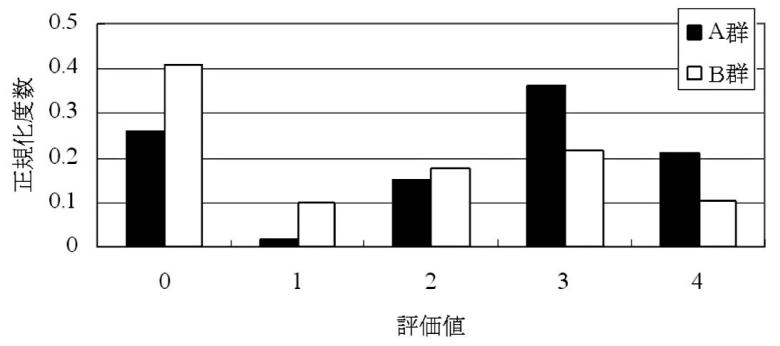

図 1 “楽しい”印象評価結果

Experimental result of "enjoyable" impression test.

ラムとして表した評価結果を図 1 に示す。評価值 0 ～2 の 低い範囲では, B 群の度数が A 群の度数を上回っているの に対し, 評価值 3，4の高い範囲では，A 群の度数の方が 高いことがわかる. A 群の平均評価值は 2.25 , B 群は 1.50 であった。これら二つの分布に正規性を仮定し，平均に有 意差があるかどうかを $\mathrm{t}$ 検定により調査した。 $\mathrm{p}$ 值はおよ そ $0.00022<0.05(5 \%)$ であり, 有意水準 $5 \%$ の下で,「2 つの分布の平均に差がない」とした帰無仮説は棄却される ことを確認した。

また，88の映像について，各映像の評価值に基づいてラ ンキングを行ったところ，上位 5 位以内のうち三つ, 10 以 内のうち五つが $\mathrm{A}$ 群の映像であった. 特に, $\mathrm{A}$ 群の上位の 映像には, “笑い”を誘発するような“楽しい”事象（出来 事）と，それを観測する人々の“笑い”が収録されているも のが多かった。この理由を考察する。映像に登場する観测 者は，その映像を視聴する視聴者と同様の立場であり，“楽 しい”事象を観測している，観測者の“笑い”という反応 は, この事象を視聴することによって発せられた“楽しい” という印象の表出である。このため, 同様にこの事象を視 聴する視聴者は, 同様に“楽しい”と感じやすく, 評価值 が高くなったと考えられる。

以上の結果と考察から, “笑い” シーンを含む CGVを視 聴した場合, “楽しい”という印象を持ちやすい傾向がある といえる。このことから，“笑い”シーンの検出によって， “楽しい”印象のシーンを速覧できる見込みが得られた。

\section{4. “笑い”シーン検出法の提案}

提案する “笑い”シーン検出法について説明する。図 2 に，提案手法のフローを示す．まず，映像に含まれる音声 信号をフレーム単位に分割し, フレーム毎に韻律特徵量を 抽出する，続いて，韻律特徴量を用いて連続する有声区間 境界を検出し, これをシーン境界としたシーン分割を行う. 最終的な “笑い”の検出は, このシーン単位で行う. 次に, フレーム毎に, 韻律特徵量に基づいて“笑い”確率を計算 する. 最後に, 分割された各シーンの “笑い”度を“笑い” 確率より計算し，この值が高いシーンを“笑い”シーンと して検出する。

\section{1 韻律特徵量抽出}

韻律は, 音高, 音圧, リズムなどにより特徵付けられる。

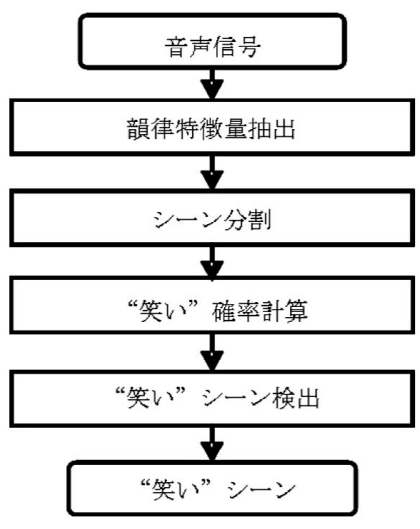

図 2 提案手法のフロー

Processing flowchart of proposed method.

表 2 韻律特徵量

Prosodic parameters.

\begin{tabular}{c|c}
\hline \hline 基本周波数 & フレーム内平均値 \\
\cline { 2 - 2 } & 短時間勾配 \\
\hline 振幅值 & $\mathrm{rms}$ のフレーム内最小值 \\
\hline パワースペクトル密度 & サブバンドパワーの平均值 \\
\hline
\end{tabular}

本稿では, 韻律特徵量のうち, 基本周波数, 振幅の $\mathrm{rms}$ 值, サブバンドパワーを抽出する，表 2 に提案手法で抽出する

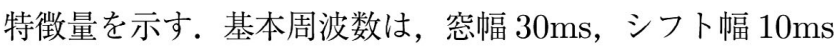
の分析フレームを用いて, 変形相関法を用いて抽出する.こ の際，倍ピッチなどの影響を低減させるために，平均化フ レームを用いて平均化する。この平均化フレームは, 空幅 $100 \mathrm{~ms}$ ，シフト幅 $50 \mathrm{~ms}$ とした. $\mathrm{rms}$ 值についても同様の 分析フレーム, 平均化フレームで抽出と平均化を行う. 以 降，単にフレームと呼ぶ場合には平均化フレームを指すも のとする。基本周波数の短時間勾配は，時間軸に対する 1 次微係数を最小自乗法によって推定して抽出する。さらに, 各特徵量の挙動を捉えるため, 対象となるフレームの前後 数フレーム分の韻律特徵量を含めてベクトル化する. 本稿 では, 前後合わせて 5 フレーム分を, 韻律特徵量ベクトル として用いた。

\section{2 シーン分割}

実際に“笑い”を検出し，速覧することを考えた場合，単 純にフレーム単位で“笑い”であると判断された区間を検 出しただけでは，笑い声のみの映像を視聴することになり， 視聴者にとって有益な速覧とはならない. そこで提案手法で は, 複数のフレームのまとまりとしてシーンを定義し, シー ン単位で速覧を可能とするためにシーン分割を行う．従来， シーンを分割するための境界としては, カット点, すなわ ちショット境界を用いることが多かった. しかしながら, 本 稿では，表 1 に示すように，カット点の存在しないような 未編集の CGV を対象とするため，この方法によるシーン 分割は有用でない。これに対し, 提案手法では, 音声の切 れ目を境界としたシーン分割を行う。

音声の切れ目は，連続有声区間の切れ目として定義する. 有声区間は，基本周波数により推定する。図 $\mathbf{3}$ に，シーン

(75) 229 


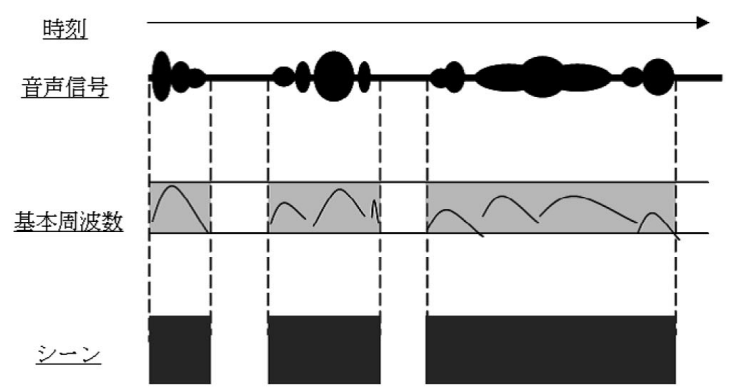

図 3 シーン分割

Scene segmentation.

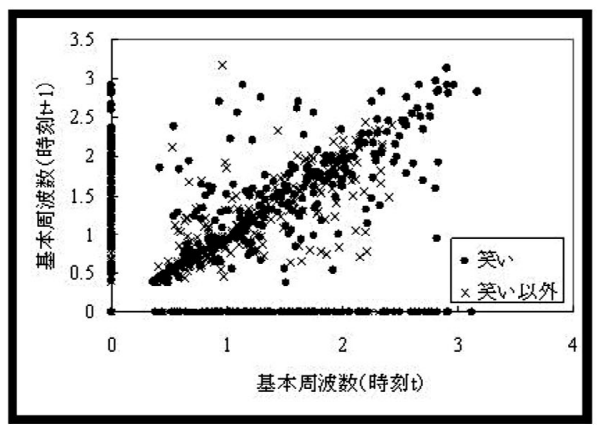

図 4 基本周波数の分布

Distribution of fundamental frequency.

分割処理の概略図を示す．基本周波数は，音声信号の最も 低周期なピーク周波数であり，人間の発話においては声带 の振動数に対応する．この性質を利用することで，基本周 波数が人間の声带振動数（拉よそ $100 \mathrm{~Hz} \sim 350 \mathrm{~Hz}^{18)}$ ) に近 い值であるかどうかを判定することによって，有声区間を 検出することができる，本稿では，有声区間ではない無声 区間の持続時間に閾値 $\tau[\mathrm{msec}]$ を設け，閾值以上の持続時 間となる無声区間を境界として，シーンを分割する。

\section{3 “笑い”確率計算}

韻律特徵量べクトルを用いて，“笑い”を含む確からしさ を確率として計算する。このような確率計算は，ある時刻 $t$ に㧍ける韻律特徽量ベクトル $\mathrm{x}_{t}$ と状態 $e_{t}$ (“笑い”, も しくは“笑い以外”の 2 值を取る) の関倸を表現するモデ ルを, 確率密度 $p\left(\mathbf{x}_{t} \mid e_{t}\right)$ として表現することによって実行 することができる，以下，本稿では $p\left(\mathbf{x}_{t} \mid e_{t}\right)$ を音響モデル と呼ぶ.

音響モデル $p\left(\mathbf{x}_{t} \mid e_{t}\right)$ は, 状態 $e_{t}$ に対する韻律特徵量ベク トル $\mathrm{x}_{t}$ の尤度を表すことができる。したがって，通常であ れば，この尤度をもってその音声が“笑い”であるか否か を判定すればよい。しかしながら，CGV の繁雑な音声にお いては，音響モデル $p\left(\mathrm{x}_{t} \mid e_{t}\right)$ のみによって “笑い”を検出 することは難しい。“笑い”と “笑い以外”について，基本 周波数のフレーム内平均値の挙動の一部をスケール変換し, 2 次元に可視化した例を図 4 に示す。この図からわかるよ うに, 韻律特徴量のみからこれらを分離し, 検出すること は現実的ではない。そこで，“笑い”の性質を仮定し，これ を利用した方法を提案する。具体的には，“笑い” の持続時

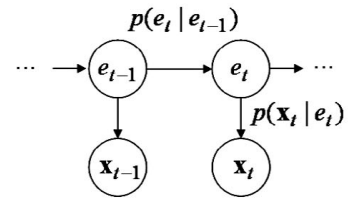

図 5 一般化状態空間表現における变数間の因果関係 Causal relation between variables in generalized state space.

間と生起に対する性質として，以下の二つの仮定を置く.

[“笑い”の持続時間と生起に関する仮定］

・“笑い”の持続洔間は，統計的にある分布にあてはめ ることができる.

・ある時刻に㧍ける “笑い”の起こりやすさは，それま での“笑い”の起こり方に依存する.

これらの二つの性質は, 状態 $e_{t}$ をマルコフ過程に従う離 散シンボル時系列とみなすことにより確率モデル化できる。 具体的には, 状態 $e_{t}$ の遷移に関する特性を $e_{t}$ の時間遷移 確率 $p\left(e_{t} \mid e_{t-1}, e_{t-2}, \cdots\right)$ として表現する。これを遷移モデ ルと呼ぶ。“笑い”は感情表出の一つであり，その時間的な 広がりを考慮して，現時刻の状態は，数時刻前の状態から 影響を受ける多段マルコフ過程としてモデル化するべきで あるが，本稿では，簡単のため，現在の状態は，一時刻前 の状態からのみ影響を受ける単純マルコフ過程として仮定 し, $p\left(e_{t} \mid e_{t-1}\right)$ とモデル化する.

以上説明した音響モデル $p\left(\mathbf{x}_{t} \mid e_{t}\right)$ と遷移モデル $p\left(e_{t} \mid e_{t-1}\right)$ に基づいて, 洔刻 $t$ までの韻律特徵量べクトルの洔系列 $X_{t}=\left\{\mathbf{x}_{t}, \mathbf{x}_{t-1}, \mathbf{x}_{t-2}, \cdots\right\}$ を観測した下での状態 $e_{t}$ の確 率 $p\left(e_{t} \mid X_{t}\right)$ が計算できる. 以降, $e_{t}=$ “笑い” である確率 を“笑い”確率とする。

韻律特徵量ベクトル $\left\{x_{t}\right\}$ と状態 $\left\{e_{t}\right\}$ の間に存在する, 図 5 に示すような因果関係を有する音響モデルと遷移モデ ルの組は，一般化状態空間表現とみなすことができる。こ のとき, $X_{t}$ を観測した下での状態 $e_{t}$ の生起確率 $p\left(e_{t} \mid X_{t}\right)$ は，音響モデル $p\left(\mathrm{x}_{t} \mid e_{t}\right)$ と遷移モデル $p\left(e_{t} \mid e_{t-1}\right)$ を用い, 以下の Bayes 型の再帰式によって求めることができる ${ }^{19)}$.

$$
\begin{aligned}
& p\left(e_{t} \mid X_{t-1}\right)=\sum_{e_{t} \in E} p\left(e_{t} \mid e_{t-1}\right) p\left(e_{t-1} \mid X_{t-1}\right) \\
& p\left(e_{t} \mid X_{t}\right)=\frac{p\left(\mathbf{x}_{t} \mid e_{t}\right) p\left(e_{t} \mid X_{t-1}\right)}{p\left(\mathbf{x}_{t} \mid X_{t-1}\right)}
\end{aligned}
$$

ただし， $E$ は，状態 $e_{t}$ の取りうる值の集合である。この再 帰式の計算は，扱う変数がすべて連続变数である場合など には，一般には解析計算不能であり，適当な近似が必要と なる ${ }^{20)}$. しかしながら，本手法においては， $e_{t}$ が離散変数 であり，このとき， $e_{t}$ の取りうる值の数を $n$ とすれば, 1 サイクルに必要な計算量は二項演算回数で高々 $O\left(n^{2}\right)$ に収 まるため，短時間で解析計算可能である。

\section{4 “笑い”シーン検出}

前節までの处理によって計算した，フレーム毎の“笑い” 


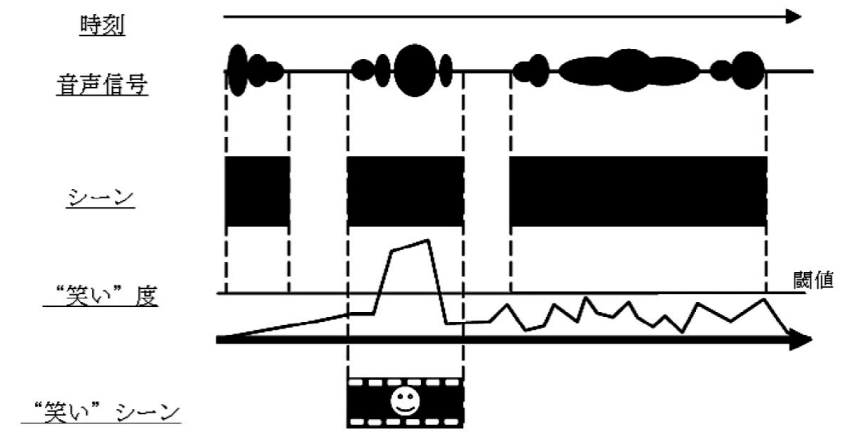

図 6 “笑い”シーン検出.

Detection of "laughter" scene.

確率に基づいて, シーン単位での “笑い”シーン検出を行 う. “笑い”シーン検出処理の流れについての概要を図 6 に 示す. 提案手法では, シーン単位での検出を行うため, フ レーム単位で計算した “笑い”確率に基づき, シーン単位 での “笑い”の強さを表す指標として “笑い”度を計算す る。本稿では, “笑い”度を, フレーム毎の“笑い”確率の 単位時間総和の最大值として定義することとする。“笑い” 度を閾值処理して，高いシーンを“笑い”シーンとして検 出する.

\section{5. 評 価 実 験}

提案手法による “笑い”シーン検出精度を評価する。ま ず，提案手法のシーン分割の妥当性を確認する。次に，提 案手法が検出した “笑い”シーンと, 人手によって判断し た“笑い”シーンとの一致性を評価する。最後に, 提案手 法で設定した“笑い”の時間遷移特性に対する仮定の正当 性と, 遷移モデルの導入による “笑い”シーン検出精度向 上の効果を検証するため, 提案手法から遷移モデルを除外 し，音響モデルのみで “笑い”シーン検出を実行した場合 についての精度を評価し, 提案手法との比較を行う。また, 結果について考察する.

\section{1 実験条件と結果}

評価用の映像としては，筆者らが実験用に作成した “笑 い”を含む 5 本の CGV を用いた。これらの実験用 CGV は, 合計約 150 分, 1 本辺り平均約 30 分の未編集の映像で あり，日常会話，レクリエーションなど実際の CGV に多 く見られる状況を，沉用の撮影機器により撮影したもので ある. 音源は, 周波数 $11.025 \mathrm{kHz}$, モノラル, $16 \mathrm{bit}$ 量子 化 PCM 音源とし, 韻律特徵量はこの音源より抽出するも のとした.

本実験の評価指標について述べる。一般的な評価指標と しては精度と再現率の二つが存在し，これらは互いに相反 することが知られている。本稿の問題においては，それぞ れ次のような意味を持つ。

・精度：検出したシーンがどれだけ正確に“笑い”シー ンであるか,

・再現率：どれだけ漏れなく“笑い”シーンを網羅的に

論 文 $\square$ 個人撮影映像を対象とした映像速覽のための“笑い”シーン検出法

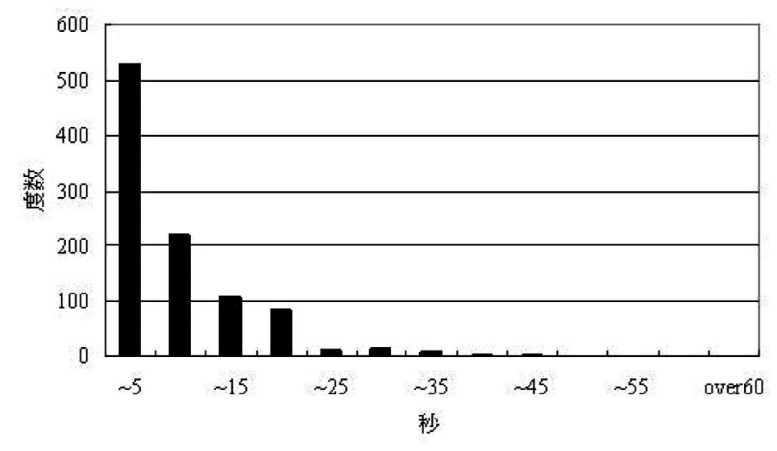

図 7 シーン長の分布

Distribution of scene duration.

表 3 実験条件.

Experimental condition.

\begin{tabular}{c|l|l}
\hline \hline 実験映像 & 種類 & 約 150 分の CGV (個人撮影映像) \\
\cline { 2 - 3 } & シーン総数 & 981 \\
\cline { 2 - 3 } & $\begin{array}{c}\text { 正解“笑い”シーン数 } \\
\text { (人手判断) }\end{array}$ & 352 (全シーン巾の $35.9 \%)$ \\
\hline \multirow{2}{*}{ モデル } & 音響モデル & 混合正規分布（混合数 5) \\
\cline { 2 - 3 } & 遷移モデル & bi-gram \\
\cline { 2 - 3 } & 学習データ数 & “笑い” ラベル数 504 \\
\hline
\end{tabular}

検出できるか.

本稿の目的は，映像中の “楽しい”シーンを短時間で視聴 するために, “笑い”を含む映像中の“笑い”シーンを速覧 する手段を提供することにある．速覧する時間は，テレビ コマーシャル映像などの長さを参考に，15６0 秒前後の時 間長を想定しており，このため，速覧する映像に含まれる シーン数は平均的には 2,3 シーン程度と少数であること が予想される。このような利用を想定する場合, 重視すべ き評価指標は, 再現率よりも, 少数のシーンを検出した際 にどの程度正確に目的の “笑い”シーンを検出できるかを 表す精度である。したがって，本実験では，提案手法が検 出したシーンに対する，“笑い”シーンの占める割合である 精度を評価指標として定義する。

まずここでは, 提案手法のシーン分割処理が，適切な長 さのシーンを構成できるかどうかを評価する。本稿では, 15 60 秒程度の速覧を想定しているが，一つ以上のシー ンを用いてこれを実現するためには，それぞれのシーンが 15６0 秒以下となることが好ましい．図 7 に，シーン分 割のための閾值 $\tau$ を $500 \mathrm{msec}$ としたときの, 提案手法の シーン分割によるシーン長の分布を示す。結果, 約 150 分 の CGV は 981 シーンに分割され，このうち，15 秒以下 のシーンの割合は約 $87.3 \%, 30$ 秒以下のシーンの割合は約 $98.5 \%, 60$ 秒以下のシーンの割合は約 $99.9 \%$ となった。こ の結果から，ほとんどのシーンが $15 \sim 60$ 秒以下となって おり，提案手法のシーン分割が適切であることが確認でき た。

“笑い”の検出精度を評価する。実験条件を表 3 に まとめる。シーン分割の結果得られた 981 シーンのうち， 正解シーンとなる人手により判断した “笑い”シーン数は 352 であった，音響モデル $p\left(\mathbf{x}_{t} \mid e_{t}\right)$ は，音声認識などのパ

(77) 231 


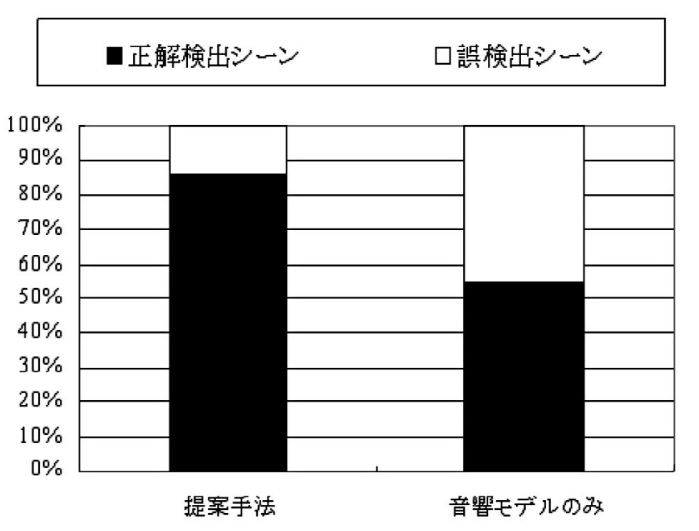

図 8 実験結果

Experimental result.

ターン認識問題における識別モデルとしてよく用いられる 混合正規分布 ${ }^{21)}$, 遷移モデル $p\left(e_{t} \mid e_{t-1}\right)$ は, 4.3 節で述べ た理由から bi-gram とし, 各モデルのパラメータは, 人手 で判断した“笑い”ラベル（一続きの“笑い”区間）数が 504 の約 250 分の CGV の音声から学習によって決定した. 学習法は, 音響モデル $p\left(\mathbf{x}_{t} \mid e_{t}\right)$ に対しては, 期待值最大化 (Expectation-Maximization algorithms: EM) 法, 遷移 モデル $p\left(e_{t} \mid e_{t-1}\right)$ に対しては最尤推定法を用いた.

まず，提案手法の精度について述べる. 図 8 に実験結果 を示す. 提案手法が “笑い”シーンとして検出したシーン 数は 161 であり，このうち正解の “笑い”シーンと一致し たシーン数は 133 であった。この結果, 提案手法が検出し たシーンのうち, “笑い”シーンの割合は, $82.6 \%$ と高い ことが確認できた。

次に，遷移モデル導入による効果を検訨するため，音響 モデルのみを用いて検出を行った場合との比較実験につい て述べる，音響モデルのみを用いて“笑い”シーンを検出す る方法としては, 音響モデル $p\left(\mathbf{x}_{t} \mid e_{t}\right)$ の值を, “笑い” 確率 であるとみなして“笑い”度を計算し，これを閾值処理す ることで “笑い”シーンの検出を行うものとした.ここで は，基準を合わせるため，検出シーン数が提案手法のもの と同じ 161 シーンになるように, 閾值の調整を手動で行っ た. 結果, 正解の “笑い”シーン数は 88 であり, 音響モデ ルのみを利用した方法の場合, その検出精度は $54.0 \%$ で あった. 図 8 に示した比較からもわかるように，遷移モデ ルを導入することによって，提案于法の精度が大きく改善 されていることが確認できる。このことから，“笑い”の時 間遷移特性の正当性と, 遷移モデルを導入することによる 効果を確認できた.

\section{2 考 察}

誤検出の原因について考察する. 提案手法では, 発声の リズムが“笑い”と似た挙動を持っている会話音声を“笑 い”として誤検出しやすかった。この理由は, 提案手法が, 音高やリズムを表す韻律特徵量のみを参照していることに
あると考えられる，発声のリズムは，韻律特徴量中の基本 周波数の挙動や出現の仕方などに表れており，これが類似 しているものは“笑い”であると誤りやすい.この影響を低 減し, さらに精度の向上を図るためには, 韻律特徵量のみ ではなく，母音の情報などを含む音韻特徵量を利用するこ とが考えられる。しかしながら, 音韻特徵量は, 雑音の影 響を受けやすい比較的高次のスペクトル情報を解析する必 要がある. 表 1 に示した CGV の性質を考えれば，これを 抽出するのは容易ではなく, 別途, 適当な雑音抑圧手法を 導入するなどの工夫が必要であると考えられる，一方，検 出漏れしやすい“笑い”については，複数の話者による“笑 い”が同時に起こっている場合があげられる。このような 場合の音声では, 変形相関法では基本周波数が抽出できず, 欠撌してしまう場合が多い.このため, 提案手法において は“笑い”であると判断されず，漏れとなったと考えられ る.このような漏れに対しては, 基本周波数を頑健に抽出 する方法の導入，もしくは，基本周波数を利用しない韻律 特徴量ベクトルによる方法を検討する必要があると考えら れる。

また，本実験では，実際に流通する CGVではなく，実 験用 CGV を用いている。このことについて，本実験の妥 当性を考えた場合, “笑い”の検出精度を評価することを目 的とした本実験では, 実験用 CGVの音声的な性質が, 実 際の CGVのそれに近いことが重要である. 前述のような 条件で作成された実験用 CGV はこれを満たしており，本 実験対象として妥当であるといえる。したがって，実際の CGVに提案手法を適用した場合にも，本実験で得られた検 出精度と比較して大きな性能の劣化はみられないと予想す る。しかしながら，映像共有サイトなどに流通する実際の $\mathrm{CGV}$ は, 平均的には $2 \sim 3$ 分程度の映像が比較的多く見ら れ，本実験で用いた実験用 CGV とは映像 1 本あたりの時 間長に差が存在するなど, いくつかの差異も存在する。こ のため, 今後, 提案手法の利用効果を検証する場合には, よ り実用的な条件下で適切な評価指標を導入し, 実際の CGV を用いた実験を行う必要があると考える。

\section{6.むすび}

本稿では, 最近利用の進む CGV に着目し, “楽しい”シー ンを速覧するための手段を提供する目的の下，映像中の“笑 い”シーンを検出する方法を提案した. “笑い”シーンを含 む映像を視聴した際, “楽しい”という印象を持ちやすい傾 向があることを確認した。提案手法は,

・安定して抽出可能な韻律特徵量のみを用いる，

・遷移モデルを導入する，

の 2 点を特徴としている。これらの特徴によって, CGVに おいても約 $83 \%$ の精度で “笑い” シーンを検出できること を確認した。

今後の展望としては, “笑い” シーンの検出精度の向上を 
図ること，および，提案手法が“笑い”シーンであるとし て検出したシーンを視聴した際に, 視聴者がどの程度“楽 しい”と感じるかを評価していくことが必要である。また， “楽しい”以外の印象に則した速覧を実現すべく，“笑い” シーン以外のシーンを検出するための方法を開発すること が考えられる．さらに，検出したシーンを視聴者に提示す る機能を含めたシステムを構築し, 実際の CGV に適用し た際の効果を実証するための評価実験を検討したい。

本研究の遂行にあたり，多人なご協力を頂いた NTT サ イバーソリューション研究所 林 泰仁主幹研究員, 国士舘 大学中鴧信弥教授，および，日ごろ研究をご支援頂いてい る武井 香氏, 町口恵美氏に感謝致します。

\section{〔文献〕}

1）日高浩太, 他:“音声の強調情報を利用したビデオコンテンッ短縮視聴 方法の検討”, 画電学誌, 35, 5, pp.505-511, (2005)

2）日高浩太, 藤川 勝, 宮下直也, 位藤 隆 :“映像ダイジェスト配信システ ム「チョコパラ T V」における情報記述方式 CH-RSS の提案”，第 2 回 DCS (Jun. 2006)

3）湯口昌宏, 宮下直也, 日高浩太, 佐藤 隆: “映像ダイジェスト配信シス テム「チョコパラTV」の開発”, 第 2 回 DCS (Jun. 2006)

4) “Yahoo!映画": http://movies.yahoo.co.jp/

5) "BIGLOBE VIDEO STORE": http://broadband.biglobe.ne.jp /vstore/

6) H.-B. Kang: "Affective Content Detection using HMMs," Proceedings of the eleventh ACM international conference on Multimedia, pp.259-262(2003)

7) M. Xu, L.-T. Chia, and J. Jin: "Affective Content Analysis in Comedy and Horror Videos by Audio Emotional Event Detection," IEEE International Conference on Multimedia \& Expo. 2005(Jul. 2005)

8) A. Hanjalic, and L.-Q. Xu: "Affective Video Content Representation and Modeling," IEEE Trans. Multimedia, 7, 1, pp.143154(2005)

9）入江 豪，他:“CGM 映像を対象とした感情表出区間自動検出法”, 信 学総全大 (Mar. 2007)

10）入江 豪, 日高浩太, 佐藤 隆, 谷口行信: ““笑い”シーンの自動切出 し法の提案”, 第 3 回 DCS (Jul. 2007)

11）北原義典, 東倉洋一：“音声の韻律情報と感情表現”, 信学技報, SP88, 158 , pp.27-32 (Mar. 1989)

12) R. Cowie, et al.: "Emotion Recognition in Human-Computer Interaction," IEEE Signal Processing Magazine, 18, 1, pp.3280(Jan. 2001)

13) N. Tosa and R. Nakatsu: "Life-Like Communication Agent Emotion Sensing Character "MIC" \& Feeling Session Character, "MUSE"-", 1996 International Conference on Multimedia Computing and Systems, pp.12-19(1996)

14）柴崎昆一, 光吉俊二:“抑揚加の感情認識の評価 一感性制御技術 (ST) の評価と, 人間の感情の評価法についてー", 信学技報, TL2005, 105, 291, pp.45-50 (2005)

15) J. Imai, H. Tanaka, and T. Nagashima: "Analysis of Nonlinearities in Nonverbal Voices," KANSEI Engineering International, 5, 3, pp.7-14(Dec. 2005)

16）松村雅史, 辻竜之介：“笑い声の無拘束・長時間モニタリング-爆笑計一”, 信学技報, SP2005, 105, 370, pp.78-83 (Oct. 2005)

17) "ClipLife" : http://cliplife.jp/

18）電子通信学会 編:“聴覚と音声”, コロナ社（Sep. 1966）

19) G. Kitagawa: "Non-Gaussian State-Space Modeling of Nonstationary Time Series," Journal of American Statistical Association, 82, pp.1032-1063(Dec. 1987)

20）北川源四郎：“モンテカルロ・フィル夕および平滑化について”, 統計数 理, 44, 1, pp.31-48 (1996)

21） L. Rabiner, and B.-H. Juang, 古井貞熙（監訳）：“音声認識の基 礎（下）”，NTTアドバンステクノロジ株式会社, pp.138-140（Nov. 1995)

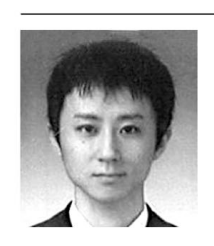

“”江 豪 2006 年, 慶應義熟大学大学院理工学 研究科修士課程修了. 同年, 日本電信電話株式会社入社. 現在, NTT サイバーソリューション研究所勤務. 音声 の統計处理の研究に従事.

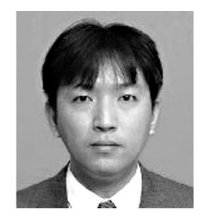

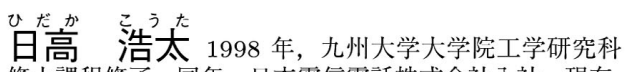
修士課程修了. 同年, 日本電信電話株式会社入社. 現在, NTT サイバーソリューション研究所研究主任. 主に, 音 声処理の研究に従事.

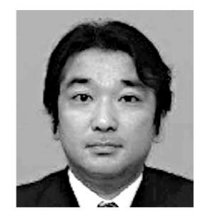

袈芐㚗也 1997 年, 成蹊人学人学院工学研究科 修士課程修了. 同年, 日本電信電話株式会社入社. 現在, NTT サイバーソリューション研究所研究主任. 主に, 映 像・音声メディアの研究に従事.

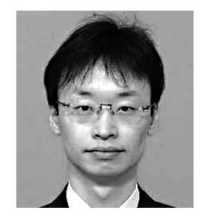

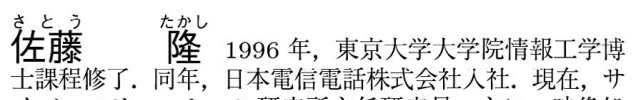
イバーソリューション研究所主任研究員. 主に, 映像処 理, 映像 DB の研究開発に従事. 正会員.

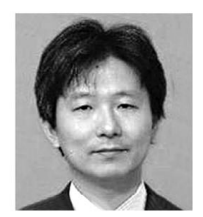

器口行告言 1992 年, 東京大学大学院工学系研究 科修士課程修厂。问年, 日本電信電話株式会社入社. 現 在, NTT サイバーソリューション研究所主幹研究員. 主 に, 映像メディア処理技術, メディアナビゲーション技 術の研究開発に従事. 博士 (工学). 正会員. 